\title{
Esetleges siker, rendszerbe kódolt kudarc
}

\author{
Kovács Edina
}

\author{
Felsőoktatási Kutató és Fejlesztő Központ (CHERD-H) kutató \\ kovacs.edina.12@gmail.com
}

Fehérvári Anikó és Tomasz Gábor (szerk.): Kudarcok és megoldások. Iskolai hátrányok, lemorzsolódás, problémakezelés. Oktatáskutató és Fejlesztó Intézet, Budapest. 252 oldal https://mek.oszk.hu/15 600/15610/

DOI: 10.37205/TEL-hun.2019.1-2.10

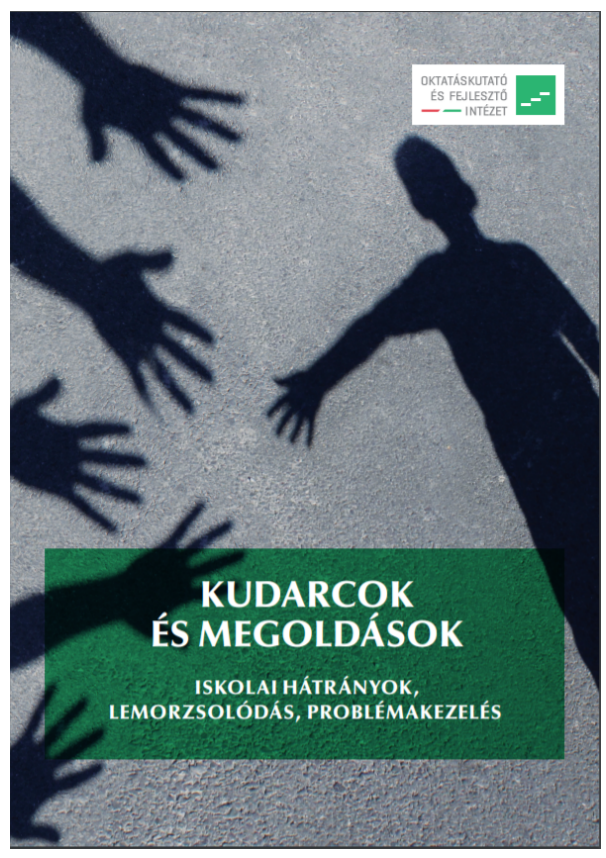

Az iskolai lemorzsolódást vizsgálva egyedül Magyarországon tapasztalunk trendszerü romlást: 2010 óta - az addigi csökkenéssel szemben - növekszik a lemorzsolódó diákok aránya, így egyre távolabb kerülünk a nemzeti és egyben európai uniós 10 százalékos célértéktől. Ez a sajnálatos tény az egyik legfőbb megállapítása az Oktatáskutató és Fejlesztő Intézet 2015-ös, Kudarcok és megoldások. Iskolai hátrányok, lemorzsolódás, problémakezelés címủ tanulmánykötetének. A Fehérvári Anikó és Tomasz Gábor által szerkesztett kiadvány alaposan, több oldalról járja körül a lemorzsolódás kérdését; a tanulmányok minden esetben tisztázzák az esetlegesen nem egyértelmű fogalmakat, átfogó kontextusba helyezik a kutatási eredményeket. Ezek az eredmények Magyarországon alapvetően rosszabb helyzetről számolnak be, mint amit a korábbi években láthattunk, miközben a sikeresség dimenziói is megjelennek; ám utóbbiakat nagyban behatárolja, hogy az adott iskola milyen településen található, milyen a tanulói összetétele, és nem utolsósorban mi az igazgató és a tantestület felfogása a hátrányos helyzetről, az inklúzióról vagy a roma diákokról.

A kötet két részből áll: az első a magyarországi helyzetet vázolja fel a közelmúltban készült kutatások alapján. Az öt tanulmány öt különböző nézőpontból közelíti meg a hátrányos helyzet és a lemorzsolódás kérdését: Hives Tamás a terü- 
leti jellemzőket veszi sorra, Fehérvári Anikó egy longitudinális vizsgálat legfrissebb eredményeit ismerteti, Széll Krisztián a pedagógusok attitüdjeit, Varga Aran$k a$ a sikeresség-sikertelenség dimenzióit mutatja be, míg Berényi Eszter a pedagógusok narratívái alapján a szakképzés helyzetét elemzi. A második rész hét európai ország helyzetéről és megoldási kísérleteiről számol be, majd egy nyolcadik fejezetben Mihályi Krisztina összegzi az országtanulmányok tanulságait.

Korábbi kutatások eredményeiből tudjuk, hogy a hátrányos helyzetű és/vagy roma tanulók aránya az ország észak-keleti és dél-nyugati megyéiben a legmagasabb: Híves Tamás területi elemzése megerősíti ezen ismereteinket. Ami a sokrétü vizsgálódás - talán - meglepő eredménye: a Dél-Dunántúl hátrányos helyzetű térségeiben alacsonyabb a sok igazolatlan órával rendelkező, az évfolyamismétlő és a túlkoros tanulók aránya, mint az északkeleti térségekben. Azaz a társadalmi környezet és az iskolák is kevésbé befogadók az Észak-Alföldön, míg a DélDunántúlon valószínűleg hatékonyabban müködik a hátrányos helyzetủ általános iskolai tanulók oktatása.

$\mathrm{Az}$ is kiderül, hogy a hátrányos és a halmozottan hátrányos helyzetre vonatkozó szabályozó megváltozása miatt 2014-ben a halmozottan hátrányos helyzetű tanulók aránya tíz százalékkal, míg a hátrányos helyzetủ tanulóké 15 százalékkal csökkent, és ez elsősorban a szakközépiskolákat érintette. Ami ettől független: a lemorzsolódás aránya magas, és - a nemzetközi eredményekkel összhangban leginkább az első évfolyamokat érinti: a 8. évfolyamhoz képest a 10. évfolyamra kevesebb, mint a felére (közel 6000 fővel) csökken a diákok létszáma.

Fehérvári Anikó tanulmánya az időbeli változásokat elemzi: egy 2006/2007-es és egy 2014-es adatfelvétel alapján az iskolavezetők és a pedagógusok attitűdjeit, a hátrányos helyzetủ diákokra és a roma tanulókra vonatkozó szemléletét és az integráltan oktató iskolák helyzetét. Összességében az látszik, hogy az eltelt hét év alatt a helyzetkép minden tekintetben romlott. A leginkább szegregált iskolákban tanít a legtöbb pályakezdő, holott ezekben az intézményekben kellene legerősebben támaszkodni a tapasztalt, pedagógiai eszköztárukban sokféle megoldási mintát felvonultató tanárokra. A tanárhiány is ezekben az iskolákban a legnagyobb - vélhetően összefügg ezzel a pályakezdők fokozottabb jelenléte - és a munkaerőhiány átlagosan 2,1\%-ról 2,7\%-ra nőtt a vizsgált időszakban.

A pedagógusok az iskolai kudarcokért alapvetően a családokat teszik felelőssé: csak kevesen látnak esélyt arra, hogy az iskola kompenzálni tudja a hozott hátrányokat, és háromszor többen gondolják 2007-hez képest, hogy az iskola egyálta- 
lán nem képes erre a feladatra. A tanárok véleménye szignifikánsan összefügg azzal, hogy milyen arányban találhatók roma diákok az adott iskolában. Minél több roma tanuló van egy intézményben, a pedagógusok annál alacsonyabbnak vélik az iskola szerepét a kudarcokban. Ugyanakkor a családi okok esetében az összefüggés nem lineáris: közepes arány esetén a pedagógusok kevésbé hibáztatják a családot, mint azokban az iskolákban, ahol alacsony vagy magas a roma tanulók aránya.

Hasonló az összefüggés abban is, hogy milyen a roma diákok aránya, továbbá, hogy a tanárok a homogén, illetve a vegyes oktatás hívei inkább. Azok a tanárok tartják előnyösnek az integrált oktatást, akik közepes arányú roma diáksággal bíró iskolában dolgoznak, míg az alacsony és a magas arány egyaránt a homogén oktatást teszi kívánatossá a pedagógusok szemében.

Összességében elmondható, hogy szemléletmód tekintetében a 2006-os adatfelvételhez képest nem történt jelentős változás. Míg 2006 és 2007 között volt némi pozitív elmozdulás a hátrányos helyzetű és/vagy roma tanulók oktatásával kapcsolatos nézetek alakulásában, ez 2014-re visszaállt az első mérés szintjére. Emellett a legutolsó adatfelvétel tapasztalata az is, hogy jelentősen megnövekedett a véleményüket nem vállaló válaszadók aránya. A 2014-es eredmények utalhatnak arra, hogy a továbbképzéseknek csak átmeneti volt a hatásuk, a további fejlesztések elmaradása nem teszi lehetővé az innovatív szemlélet fenntarthatóságát.

Az előbbi kutatás adatait megerősítik Széll Krisztián eredményei, aki a 2005-ös „Integrációs program”-ban sikerrel pályázó iskolák pedagógusainak véleményét vetette össze egy országos adatfelvételben megjelenő tanári elképzelésekkel. Öszszességében azt láthatjuk, hogy a megkérdezett pedagógusok kívánatosnak tartják az etnikailag eltérő származású tanulók együttoktatását, ám a szegregált oktatást mind a roma, mind a nem roma tanulók számára jobbnak tartók aránya elég magasnak mondható (iskolatípustól is függően a tanárok körülbelül egynegyede vélekedik így), holott kutatások szerint a szegregált oktatás csökkenti a tanulmányi eredményeket és a továbbtanulási ambíciókat is; mind a roma, mind a nem roma tanulók körében. A látens diszkrimináció még erőteljesebb, amikor a pedagógusnak arra a kérdésre kellett válaszolnia, hogy milyen tanácsot adna egy barátjának gyermeke beiskoláztatása kapcsán, akkor csaknem hatvan százalékuk a képességek szerint történő elkülönítés mellett foglalt állást, vagyis az olyan iskolák mellett, ahol a gyerekeket képességeik alapján osztják homogén osztályokba, vagy akár a teljes iskolát tekintve sincs lényegi különbség az odajáró gyermekek 
között. Ugyanakkor más kutatásokból tudható, hogy a képességek fejlettségét erősen befolyásolja a családi környezet, továbbá, hogy a tanulók képesség szerinti elkülönítése növeli a tanulói teljesítmények, eredmények közötti különbségeket. Ennek kapcsán meg kell említenünk a 2013-as PISA-jelentést, amely külön kiemeli, hogy Magyarország a közé az öt vizsgált ország közé tartozik, amelyekben az iskola a legkevésbé képes kompenzálni a társadalmi hátrányokból eredő különbségeket, és a szülói szociokulturális háttér bír legerősebb hatással a teljesítményre.

A megkérdezett iskolavezetők határozottabban utasítják el a szegregációt, és az is látható, hogy a közepes méretủ, kedvezőbb tanár-diák aránnyal rendelkező intézmények pedagógusai inkább foglalnak állást a heterogén osztályok és iskolák mellett.

Varga Aranka tanulmányában azt vizsgálta, hogy az inkluzivitás mely elemei sikeresek egy az adott térség általános iskoláiban. Elemzése valamilyen módon párbeszédben áll az előző három bemutatott kutatás mindegyikével: jelzi, hogy az inklúzió szempontjából különösen érintettek köre a tudományos vizsgálatokban leírtak szerint folyamatosan bővül, miközben a hazai oktatáspolitika több ponton is szűkítette a „hátrányos helyzet” kategóriába bevonhatók körét. A szociális hátrányok mellett a kulturális kisebbségi csoporthoz tartozás felerősíti a negatív társadalmi mechanizmusokat, egy nemzetközi kutatás szerint több helyütt főként a migráns gyerekeket, míg nálunk a roma/cigány csoporthoz tartozókat sújtja ez a helyzet. Emellett Magyarországon is elsősorban az alacsony jövedelmű és iskolázatlan szülők gyerekei azok, akik jellemzően sikertelenebb iskolai utat járnak be, és erősen veszélyeztetettek a korai iskolaelhagyás tekintetében.

A sikertelen intézmények mindegyike községben található, ami megerősíti, hogy a településhátrány erős negatív hatással van a tanulói sikerességre. A sikeresség a nagyobb, míg a sikertelenség a kisebb intézményekre jellemző. Minél alacsonyabb tanulói sikerủ intézményi kategória válaszait nézzük, annál nagyobb mértékben tartják az adott kategóriába tartozó pedagógusok jellemzőnek a cigányságra vonatkoztatott sztereotípiákat. Igaz ez a megállapítás az ingerszegény környezettől a nagyobb tánctehetségen és a szülői nemtörődömségen keresztül egészen a helytelen életmódig. Ezzel szemben a roma tanulók sikertelenségének okát intézményi felelősségi körbe a sikeres iskolák pedagógusai sorolták nagyobb mértékben, és a lemorzsolódásuk okaként a problémás gyerektől való szabadulást mint intézményi problémát ők nagyobb arányban jelölték. 
A „sikeres” kategóriában 95 százalék, míg a „sikertelen”-ben 85 százalék a f”állású pedagógusok átlagaránya. A stabil, felkészült és jól együttműködő tantestület tehát mindenképpen hat a tanulói sikerességre. A sikeres intézményekben gyakorlatilag nincs hiányzó pedagógus, a többiben van.

A pedagógusok arról is kifejtették a véleményüket, hogy milyen ismeretek szükségesek a roma gyerekek sikeres oktatásához. A válaszok alapján arra lehet következtetni, hogy az elmúlt évek sokféle képzése „végigsöpört” ugyan valamennyi iskolán, ám a megszerzett ismeretek nem jelentettek elég kapaszkodót a pedagógusok számára a roma tanulókkal kapcsolatos iskolai problémák kezelésében. Különösen igaz ez a sikertelenebb iskoláknál, ahol halmozódnak a problémák, és a tanárok a gyakorlatba ültetve szeretnének megoldásokat látni. Látható azonban, hogy éppen ez a gyakorlatba ültetési szakasz maradt el a továbbképzési folyamatban, így rendkívül esetleges az elméleti ismeretek hasznosulása.

Berényi Eszter az előzőekhez képest más területet vizsgál: a szakképzés narratíváit gyüjti össze. Elemzéséből kiderül, hogy a pedagógusok körében nem egyértelmű a tankötelezettségi kor 16 évre csökkentésének megítélése, vegyes vélemények hangzottak el az interjúkban. A tanárok úgy látják, hogy általánosságban a tanulók hozzáállását ez a tény nem befolyásolja, az viszont nyilvánvalónak tünik, hogy a nagyon nehéz esetként kezelt tanulóknál ez adminisztratív értelemben mindenképpen megkönnyítheti a nevelőtestület helyzetét.

Ugyanakkor az új szakképzési struktúra miatt több helyen panaszként fogalmazódott meg, hogy - ellentétben a korábbi 2+2-es rendszerrel - menet közben a diáknak nincs lehetősége a szakmaváltásra, ha mégis kiderülne, hogy rossz tanulmányi eredményeinek, mulasztásainak oka, hogy nem kedveli a szakmát, amelyet tanul. Úgy tűnik, hogy a rugalmas tanulási út engedélyezése fontos feltétel lenne az iskolarendszerből végzettség nélkül kikerülők számának csökkentéséhez; az interjúalanyok közül többen hangsúlyozták, hogy a menet közbeni rugalmassággal több, amúgy lemorzsolódó tanuló megtartására nyílhatna esély. Berényi idézi az egyik megkérdezett kisvárosi iskolaigazgatót: „...a 2+2-ben megvolt az, hogy 910.-ben én fel tudtam zárkóztatni a gyereket. Itt ugye már erre nincs lehetőségem, pedig már konkrétan megvan a szakmai számítás, de amikor egy alapvető szorzást, vagy egy problémával küzdő gyerek mondjuk nem tudja a szorzótáblát, tehát ennyire egyszerúen fogalmazok, azt egy szakmai gyakorlati órán nem tudja a szakmai tanár kompenzálni abban a kevés óraszámban. De ott azért a 2+2-ben én azt gondolom, hogy volt ilyen korrekcióra lehetőség, itt nagyon nehéz." (92. o.) 
Az interjúkból azonban nemcsak ez derült ki, hanem az is, hogy önmagában a tanulmányi okokból történő lemorzsolódás nem igazán jelentős, a hiányzásokkal való összefüggés jóval erősebb. Ahol a szakképző iskola sikeres, ott a háttérben komoly szakmai munka zajlik, például alkalmazzák a resztoratív konfliktuskezelés módszerét, vagy minden héten esetmegbeszélő stábot tartanak a pedagógusok számára.

Az iskolák többségében egybehangzó állítások szerint a 9. évfolyamon a legjelentősebb a lemorzsolódás, és az iskolák egy része magától értetődőnek veszi, hogy bizonyos mennyiségü lemorzsolódással mindenképpen számolni kell.

A hazai és a nemzetközi rész tanulmányai között érdemes kitérni a „2011. évi CXC. törvény a nemzeti köznevelésről” azon intézkedésére, amely leszállította a tankötelezettség korhatárát 16 évre. A magyarországi kutatások ennek következményeire kevéssé térnek ki, és ha mégis, akkor azt látjuk, hogy hatásának megítélése nem egyértelmű. Az európai országok áttekintéséből viszont kitűnik néhány sarkalatos pont a tanköteles kor kapcsán. Az egyik, hogy nincs egységes európai gyakorlat, viszont egyik országban sem csökkentették a korhatárt, azaz a kialakult status quo-t nem, vagy csak az emelés irányába változtatták meg. A másik, hogy a lemorzsolódás veszélye az iskolaváltások idején a legnagyobb. Azaz a hazai korhatárcsökkentés nem önmagában probléma, hanem azért, mert épp az iskolaváltás idejére esik. Ahogyan ezt a Hálózat a Tanszabadságért 2011-ben megfogalmazta: „[az oktatási rendszerrel való] harmóniáról - esetleg - akkor beszélhet nénk, ha a 17. életév lenne a korhatár, és csak azok esetében, akik hat éves korukban kezdik az iskolát, és nem veszítenek közben sem évet. Hogy ezt lássuk, ahhoz csak össze kell adni az iskolakezdés előtt, majd az általános iskolában, valamint a szakiskolában eltöltött évek számát, de akkor nem 16-ot, hanem 17-et kapunk $(6+8+3=17)$." $^{1}$ A harmadik pedig, hogy számos országban nem feltétlenül a hagyományos oktatási rendszer keretei között igyekeznek megtartani a hátrányos helyzetủ fiatalokat, ami azonban nem jelenti azt, hogy nincs támogató rendszer és/vagy statisztikai adatgyűjtés arról, hogy mi történik az iskolapadból eltűnő diákokkal.

A vizsgált országok közül talán a dán szemlélet a legizgalmasabb: azt vallják, hogy nem kell sietni a bizonyítványok megszerzésével, a cél, hogy 24-25 éves korára mindenki rendelkezzen valamilyen szakképzettséggel. Nagy a lemorzsolódás,

${ }^{1}$ Hálózat a Tanszabadságért (2011): A HAT válaszai az Oktatási Államtitkárságnak. https://tte.hu/a-hat-valaszai-az-oktatasi-allamtitkarsagnak/ Letöltés ideje: 2019. 06. 24. 
de akinek nincs végzettsége, az 25 éves koráig gyakorlatilag kötelezően vesz részt valamilyen programban. A dán szakpolitika a lemorzsolódást illetően jelenleg a középiskolásokra fókuszál, de távlati cél a 25, majd a 30 éves korosztály bevonása a programokba. Vannak ifjúsági pályaorientációs központok, ahol minden lemorzsolódó megjelenik, mivel nincs bejelentve az iskolába, és nem fizet jövedelemadót, így őket megkeresik, képzésre motiválják. A korai iskolaelhagyás 2007 óta folyamatosan csökkenő tendenciát mutat, jelenleg 8 százalék (ahogyan már más tanulmányok kapcsán említettük, Magyarországon 2010 óta ismét emelkedik, a 11 százalékot is meghaladja).

A holland helyzet és szemlélet meglehetősen hasonló a dániaihoz: a középfokú programok között viszonylag könnyü az átjárás, a fő cél, hogy senki ne legyen korai iskolaelhagyó. A mutató egyenletesen csökken: 2002-ben 15 százaléknál magasabb volt, 2013-ra 9,2 százalékra csökkent. A tankötelezettséget 16 évről 18 évre emelték, illetve addig tart, amíg a fiatal el nem éri az ISCED 3 szintet. Pluszforrások járnak az iskoláknak, ha a hátrányos helyzetủ diákokat meg tudják tartani.

Érdekes az az elemzés, amely a holland korai iskolaelhagyók vonatkozásában a következő típusokat találta: az első csoport a racionális iskolaelhagyóké, akiknek jó okuk van az iskola elhagyására, például jó munkalehetőséget kapnak; a második csoportot azok alkotják, akik valamilyen oknál fogva nem tudnak jól teljesíteni; a harmadik csoportot azok teszik ki, akik magántermészetű vagy iskolai okokból küzdenek problémákkal, ezért kerülnek stresszhelyzetbe. A holland szemléletben a lemorzsolódás társadalmi és gazdasági probléma, a hangsúlyt a prevencióra kell helyezni.

Ha a Magyarországéhoz inkább hasonlítható helyzetű országot keresünk, a litván tanulmány szolgálhat megfontolandó adatokkal. A valamikor volt szovjet tagállam már most teljesítette a 2020-ra előírt európai uniós célértéket, a korai iskolaelhagyók aránya 2012-ben csupán 6,5 százalék volt. A korai iskolaelhagyás és lemorzsolódás csökkentésében vitathatatlanul fontos szerep jut a stabil és megbízható adatokra támaszkodó jelzőrendszernek. A litván oktatási törvény értelmében helyi szinten az önkormányzati hatóságok és az oktatási intézmények kötelesek minden 16 év alatti gyermeket nyilvántartani a tanulói regiszterben.

A szakképzés modularizációja folyamatosan zajlik, egy, a Képesítési és Szakképzés-fejlesztési Központ által irányított projekt keretein belül. A moduláris rendszert két lépésben vezetik be. Az első lépésben a moduláris szakképzési rend- 
szer és tantervek kereteit fektetik le. Ezt követően a jelenlegi tantárgy alapú szakképzési tantervet átalakítják a korábban kidolgozott modellnek megfelelően. A lemorzsolódás problémáját az országban elsősorban a 16 év alatti, tanköteles korú diákok körében igyekeznek megoldani, a policy dokumentumokban korai lemorzsolódónak nevezik ezt a célcsoportot.

Kiemelendő még a szomszédos Ausztria helyzete, amely sok szempontból hasonló a magyarhoz, ám van egy lényeges kivétel: a korai iskolaelhagyás Ausztriában - nemzetközi összehasonlításban - inkább alacsonynak mondható, ráadásul a 2008-as világválság óta folyamatosan csökken, a legutóbbi mérés szerint mindöszsze 7,4 százalék.

A különböző kutatásokból, vagy a PISA-felmérésekből jól látszik, hogy az iskolai - tanulmányi eredményekben mért - sikeresség Ausztriában is nagymértékben függ a család szocioökonómiai hátterétől, a szülők legmagasabb iskolai végzettségétől. Az elméleti lehetőségek ellenére Ausztriában nem kellő mértékủ az átjárhatóság a különböző iskolatípusok között, az osztrák iskolarendszer az inkább szegregálók közé tartozik. A munkanélküli szülők gyermekei például háromszor nagyobb valószínűséggel kerülnek ki idő előtt az iskolarendszerből, az alacsony iskolai végzettségű szülők gyermekei ötször nagyobb arányban válnak korai iskolaelhagyókká, mint a magasan kvalifikált szülők gyermekei.

A korai iskolaelhagyás kezelése Ausztriában a szakképzésre fókuszál (foglalkoztatásorientált megközelítés), és legfőbb célja a fiatalok munkaerőpiaci integrációja.

Összességében, a hét ország - Ausztria, Dánia, Észtország, Franciaország, Hollandia, Litvánia és Portugália - elemzésének tanulságai alapján elmondhatjuk, hogy a lemorzsolódás visszaszorításában jelentős szerepet játszik a pályaorientációs szolgáltatások biztosítása; a rugalmas tanulási utak megteremtése; a korai jelzőrendszer kialakítása, melynek feltétele az egyéni szintű nyomon követés; az oktatás szempontjából hátrányos helyzetben lévő területek/intézmények/egyének extra támogatása, továbbá a lemorzsolódott fiatalok mielőbbi visszavezetése az oktatásba.

Az Európai Unió 2020-ig kidolgozott gazdasági-társadalmi stratégiájában az öt elérendő célérték egyike a korai iskolaelhagyók arányának 10 százalék alá csökkentése. Az egyes országok saját maguk tűzhették ki nemzeti céljaikat. A vizsgált országok esetében Dánia, Magyarország és Portugália 10 százalékot vállalt; Ausztria, Észtország, Franciaország, Hollandia és Litvánia ennél valamivel alacsonyabb 
érték elérését célozta meg. Magyarországot leszámítva elmondható, hogy a nemzeti statisztikák közelítenek a kitűzött értékekhez. A fenti országok közül egyedül Magyarországon tapasztalunk trendszerú romlást, ahol az elmúlt években távolodott az érték az EU-s és egyben a nemzeti, 10 százalékos céltól.

Egyértelmúen látszik, hogy a problémával küzdő diákok támogatását minél korábbi életszakaszban el kell kezdeni: így megnő az esélye annak, hogy sikerül őket benntartani az oktatási rendszerben és végzettséghez juttatni. Ez közgazdasági szempontból nagyon fontos. Egyrészt azért, mert a középfokú végzettség hiányából adódó munkaerőpiaci kirekesztettség - például a munkanélküliség, a romló egészségi állapot, a bűnözés költségei formájában - súlyos terheket ró a társadalom egészére. Másrészt az iskolától elidegenedő fiatalok oktatásba, képzésbe történő hatékony visszavezetése csak magasabb költségű programok keretében lehetséges, az időben történő beavatkozás költségvonzatához viszonyítva. A prevenció tehát kiemelt fontosságú, amelynek elsődleges eszköze a kisgyermekkori nevelés széles körben elérhetővé tétele, valamint a befogadó iskolai légkör kialakítása.

Lényegesnek mutatkozik továbbá már alsó középfokon a pályaorientációs szolgáltatások biztosítása, amely például Dániában és Észtországban hatékonyan müködik, mindenki számára elérhető, de főként a kiemelten veszélyeztetett csoportokat célozza.

Ismeretes, hogy a lemorzsolódás szempontjából kritikus időszak a különböző iskolai szintek közötti átmenet. Magyarországhoz hasonlóan a vizsgált országokban is jellemző a magas arányú lemorzsolódás a szakképzés első évfolyamáról. A megelőzés egyik eszköze az említett pályaorientációs szolgáltatások erősítése az alsó középfokon tanulók számára, másik fontos és hatékonynak mutatkozó kezelési mód az alsó és felső középfok átmenetét megkönnyítő programok, szolgáltatások beépítése.

Az esélykülönbségek csökkentésének egyik hatékony eszköze a komprehenzív általános iskola, illetve a minél későbbi szelekció. Ennek jelentősége legalább két pilléren nyugszik: az egyik, hogy minél tovább ugyanazt tanulják a fiatalok, ami segíti a lemaradással küzdők felzárkóztatását, a másik, hogy a programok közti átjárhatóság viszonylag egyszerü.

A kötet két részét összevetve arra a következtetésre jutunk, hogy a magyarországi trendszerủ romlás nem véletlen, a hazai folyamatok épp a kívánatossal ellentétes irányúak. A szakképzés átalakítása során csökkent az átjárhatóság, a tanulási út rugalmassága. A tankötelezettség korhatárának csökkentése, épp az is- 
kolaváltás időpontjára, szintén a lemorzsolódás esélyét növeli. A korai beavatkozások pedig esetlegesek: a halmozottan hátrányos helyzetủ és/vagy roma diákokat nagy arányban oktató iskolákban a legnagyobb a tanárhiány és a legtöbb a pályakezdő pedagógus, a továbbképzések pedig nem képesek tartósan innovatív szemléletet megalapozni. 